where investigations into problems of the dried grape fruits industry have been in progress for many years. The other will house the Forest Products Division, which hitherto has carried on in temporary quarters in Melbourne. The new laboratory, to cost $£ 25,000$, will be in the midst of the city's timber yards, and this should mean decided increase in the practical effectiveness of the Division's work.

\section{Geographical Association}

The Spring Conference of the Geographical Association will be held at University College, Nottingham, on April 26-29. The meeting will include, in addition to several lectures and discussions, a long excursion to Southwell and Ollerton and visits to the tobacco factory of Messrs. J. Player and Sons, the hosiery factory of Messrs. J. B. Lewis and Sons, and Messrs. Boots new chemical factory. Members will be accommodated as far as possible in the Hugh Stewart Hall of Residence. Applications for accommodation and attendance at excursions should be made, before April 6, to Mr. N. V. Scarfe, University College, University Park, Nottingham.

\section{Astronomical Exhibition in Paris}

At the next General Assembly of the International Astronomical Union, to be held at Paris on July 10-17, the French National Committee of Astronomy is arranging an exhibition of astronomical documents and apparatus, to exhibit the principles and the details of application of the methods of observation employed. The examination of actual instruments shows better than any description how they are applied, while original negatives or positives on glass will enable the quality of the results obtained to be judged. The exhibition will enable astronomers to examine the documents serving as the foundation of the astronomical discoveries of the present century. It is particularly hoped that auxiliary apparatus and accessory contrivances of all kinds will be exhibited by observatories and instrument makers: such instruments are micrometers, chronographs, photometers, spectrographs, driving motors, observing sheds and seats, abacuses, numerical tables and calculating machines. Inquiries can be addressed to M. le Comte de la Baume Pluvinel or to Prof. C. Fabry at the Paris Observatory.

\section{Sixth International Congress for Scientific Management}

THE Sixth International Congress for Scientific Management, the first congress of its kind to be held in Great Britain, will take place on July 15-20 and will be opened by its patron, the Prince of Wales. It will discuss commercial, agricultural and domestic problems and how far the adoption of the most scientific principles of management has facilitated their solution. Some three hundred chairmen, managing directors and professional and scientific men have so far enrolled, and the standard of the papers received from all parts of the world is most encouraging. The organisation of the Congress is in the hands of a Council convened by the Federation of British Industries. Subjects to be discussed include : manu- facturing, distribution, development, agricultural, educational and training, and domestic. There is every indication that a really important gathering will take place. H.M. Government is to invite members to a reception, and the Lord Mayor and Corporation will receive them in the Guildhall. A series of visits to factories and institutions will take place in the week following the Congress. Invitations to the Congress containing membership forms and full details may be obtained from the Secretary, 21 Tothill Street, London, S.W.1.

\section{Catalogue of Microscopes and Accessories}

We have received from Messrs. W. Watson and Sons, Ltd., the new edition of their catalogue of microscopes and accessories (Parts 1 and 2). The pages devoted to principles of construction on the optical bench system, now applied to all Messrs. Watson's microscopes, are of particular interest, and other constructional details in these pages are also noteworthy as evidence of the care devoted to the attainment of rigidity and accuracy. Attention may also be directed to the description of the dark ground condenser which can be made with working distances up to $4 \mathrm{~mm}$. and to the low-power binocular dissecting microscope, strong in build and with two pairs of objectives mounted on a double nosepiece so arranged that the pair not in use is turned into a protected position. A considerable range of lamps for various microscopic purposes includes the Greenough lamp, which rests on the table beneath the microscope stage in place of the mirror and gives an evenly illuminated field, provision being made for centring the filament.

\section{Announcements}

Sir John Ambrose Fleming has been awarded the Kelvin Medal for 1935 of the Institution of Civil Engineers in recognition of his services to electrical science and particularly of his invention of the thermionic valve. The Kelvin Gold Medal is awarded triennially as a mark of distinction in engineering work or investigation of the kinds with which Lord Kelvin was especially identified.

Aт the meeting of the Australian National Research Council at Melbourne in January, the first award of the Lyle Medal was made, the recipient being Prof. J. R. Wilton, Elder professor of mathematics in the University of Adelaide, for his work in mathematics. This medal is to be awarded, at intervals of two years, to workers in Australia for such researches in mathematics or physics as may appear to the Council most deserving of such honour, the period covered by those researches being the five years preceding each award.

THE services of Prof. R. H. Dastur, professor of botany at the Royal Institute of Science, Bombay, have been secured on loan from the Bombay Government by the Government of the Punjab for the investigation of the cotton crop. His address for some years, therefore, will be the Cotton Research Laboratory, Lyallpur, Punjab. 
The Congress of the German Röntgen Society will be held in Berlin on April 28-30 under the presidency of Prof. W. Baensch, from whom further information can be obtained at his address, Liebigstrasse 20a, Leipzig.

A Discussion on the "Origin and Relationships of the British Flora", to be opened by Prof. A. C. Seward, has been arranged by the Royal Society for the morning and afternoon of March 28. Other speakers will include Mrs. E. M. Reid, Prof. P. G. H. Boswell, Miss M. E. J. Chandler, Dr. H. Godwin, Dr. A. J. Wilmot, Prof. E. J. Salisbury, Dr. G. Einar du Rietz, Mr. H. Davey, Prof. O. T. Jones, Dr. R. L. Praeger, Dr. K. Sandford, Dr. G. C. Simpson, Mr. J. B. Simpson, Dr. W. B. Wright.

At the annual general meeting of the Microchemical Club held on March 16 at the London School of Hygiene and Tropical Medicine, the following officers were elected for 1935-36: Hon. Treasurer and Librarian, Dr. L. H. N. Cooper, Marine Biological Laboratory, Plymouth; Hon. Secretary, Dr. S. J. Folley, National Institute for Research in Dairying, Shinfield, Reading. Vacancies on the committee were filled by the election of Miss I. H. Hadfield and Dr. J. R. P. O'Brien.

THE International Association for the Prevention of Blindness will hold a meeting at the Royal Society of Medicine, 1 Wimpole Street, W.1, on April 5, during the Congress of the Ophthalmological Society of the United Kingdom. The agenda are as follows: (1) address by Prof. de Lapersonne, president of the Association; (2) proposed international classification of the causes of blindness, by Prof. van Duyse, of Ghent; (3) hereditary diseases of the eyes ending in blindness and their social consequences, by Prof. Franceschetti, of Geneva.

A symposium on the "Welding of Iron and Steel" will be held at the Institution of Civil Engineers, Great George Street, Westminster, S.W.1, on May 2-3, under the auspices of the Iron and Steel Institute, in co-operation with the principal engineering and metallurgical societies of Great Britain. The symposium will be divided into four groups, namely: (1) present-day practice and problems of welding in the engineering industries; (2) welding practice and technique, including welding apparatus; (3) the metallurgy of welding; (4) specification, inspection, testing and safety aspects of welding. Further information can be obtained from the Secretary, Iron and Steel Institute, 28 Victoria Street, London, S.W.1.

AN animal welfare society has just been formed in the Otani University, Kyoto, Japan, to be affiliated to the University of London Animal Welfare Society. Prof. Beatrice Susuki, professor of agricultural and forest chemistry, is leader and secretary. Communications addressed to the new society will be received and forwarded by the University of London Animal Welfare Society, 68 Torrington Square, London, W.C.1.
The Institute of Public Health of the University of Budapest, the sixtieth anniversary of which is to be celebrated this year, is the first institute of the kind to have been founded. In 1882, public health became a compulsory subject in the Budapest faculty of medicine and in 1893 in the faculty of pharmacy. The first director of the institute, Josef Fodor, who was also the founder of the Hungarian Society of Public Health, was a savant of world-wide reputation, and an excellent organiser, thanks to whose efforts the medical supervision of schools became generalised throughout western and southern Europe.

WE have received from the Association of British Chemical Manufacturers, 166 Piccadilly, London, W.1, a copy of "British Chemicals, 1935" (Pp. 459, bound in cloth). This is printed in English, French, German, Italian, Portuguese and Spanish, and gives the names of British manufacturers of classified products, a list of proprietary and trade names of materials, with their manufacturers, and indexes in the various languages. The volume is published gratis, but is obtainable only on direct application to the Association by genuine purchasers of chemicals.

Applications are invited for the following appointments, on or before the dates mentioned:-A temporary engineering assistant for the Directorate of Works in the War Office-The Under Secretary of State (C 5), The War Office, London, S.W.1 (March 28). A chemist for rubber research (Malaya and Ceylon)-The Secretary, London Advisory Committee for Rubber Research (Malaya and Ceylon), Imperial Institute, London, S.W.7 (March 28). A principal of the East Ham Technical College-The Secretary for Education, Education Office, Town Hall, East Ham, E.6 (March 30). Two junior assistant bacteriologists in the City Bacteriologist's Department, Liverpool-Town Clerk, Municipal Offices, Dale Street, Liverpool, 2 (April 2). An assistant agricultural officer to the Kent County Council-The Chief Agricultural Officer, Brunswick House, Buckland Hill, Maidstone (April 4). A principal of the Northern Counties' Training College of Cookery and Domestic Science, Newcastle-upon-Tyne-The Secretary, 4 Royal Arcade, Newcastle-upon-Tyne (April 8). An assistant keeper (second class) on the Higher Technical Staff of the Library of the Science Museum -The Director, Science Museum, South Kensington, S.W.7 (April 13). A research worker in cancer-The Research Director, North of England Cancer Campaign, 14 Ellison Place, Newcastle-upon-Tyne (April 14). A demonstrator in organic chemistry at Bedford College for Women, Regent's Park, N.W.1.-The Secretary (April 27). A chemist for the Main Drainage Department of the Ministry of Public Works, Egypt -The Chief Inspecting Engineer, Egyptian Government, 41 Tothill Street, London, S.W.I. A principal of University College, Nottingham-Alderman E. Huntsman, 1 Bridlesmith Gate, Nottingham.

ERratum. In the list of members of council of the National Institute of Sciences of India, printed in NATURE of March 16 (p. 442), for "Dr. Baini Prasad" read "Dr. Baini Prashad". 